\title{
OCCURRENCE OF DOUBLE-STRANDED RNA SPECIES IN CHAMPIGNON AND THEIR RELATION TO MUSHROOM VIRUS X SYMPTOMS
}

\author{
K. Halász ${ }^{\mathrm{a}}$, A. Geösel ${ }^{\mathrm{a}, \mathrm{b}}$, J. Szarvas ${ }^{\mathrm{c}}$, N. VirÁGH ${ }^{\mathrm{a}}$, Cs. Hajdúd $^{\mathrm{d}}$ and N. LukÁCs ${ }^{\mathrm{a} *}$

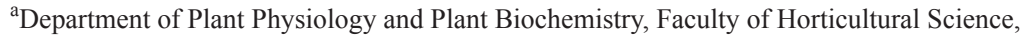 \\ Corvinus University of Budapest, H-1118 Budapest, Villányi út 29-43. Hungary \\ ${ }^{b}$ Department of Vegetable and Mushroom Growing, Faculty of Horticultural Science, \\ Corvinus University of Budapest, H-1118 Budapest, Villányi út 29-43. Hungary \\ ${ }^{\mathrm{c}}$ Department of Food Chemistry and Biochemistry, Eszterházy Károly College, \\ H-3300 Eger, Leányka u. 6-8. Hungary \\ ${ }^{\text {d} A g r i e n s i s ~ K f t . ~ H-3398 ~ N a g y t a ́ l y a, ~ P a c s i r t a ~ u . ~ 16 . ~ H u n g a r y ~}$
}

(Received: 1 October 2012; accepted: 15 January 2013)

\begin{abstract}
Mycoviruses are known to infect fungi of different habitats and life style. Some of them, like the Mushroom Virus $\mathrm{X}$ (MVX) complex, cause abnormal development of fruiting bodies and severe yield losses in mushroom cultivation. Most mycoviruses have a double-stranded RNA (dsRNA) genome, therefore dsRNA-detection is frequently used as a first step to identify virus infection. In relation with MVX 23 dsRNAs species have been described, occurring in variable number and combination in diseased mushrooms. The aim of our experiments was to find out whether dsRNA-immunoblotting can be used to detect dsRNA in small samples of cultivated A. bisporus varieties and of wild growing Agaricus species. We found that by immunoblotting, the same dsRNA species were detected in apparently healthy cultivated champignon fruiting bodies and in MVX-infected reference samples, respectively, as by conventional CF11 chromatography, but for immunoblotting a much smaller sample size was needed. In two out of three deformed fruit bodies of cultivated A. bisporus from Hungary we detected a $4.1 \mathrm{kbp}$ dsRNA species which was also present in the MVX infected reference samples. Diverse and variable dsRNA patterns were observed in apparently healthy samples of 12 wild growing Agaricus species, indicating that extreme care should be taken when non-cultivated Agaricus is used for breeding new varieties. Non-sterile cultures and environmental mushroom specimens are fairly often mixed with parasitic and endofungal organisms, therefore, we also tested fungi isolated from mushroom cultures. Here again, 1-7 dsRNA species were found in extracts of Trichoderma and Dactylium isolates and of Mycogone-infected sporophores. Our results demonstrate clearly that dsRNAs from very different origins can be present in cultivated champignon and support the view that the MVX symptom-associated dsRNAs are probably of polyphyletic origin and do not represent one defined virus.
\end{abstract}

Keywords: Mushroom Virus X, Agaricus, dsRNA, immunoblot, coexisting fungi

Champignon [Agaricus bisporus Lange (Imbach)] production accounts for a dominant portion of the Hungarian vegetable sector. One of the major risks of champignon growing worldwide is infection by viruses. From the middle of the past century till now (ElibuYuK \& Bostan, 2010) the La France Isometric Virus (LIV) caused significant yield losses, and lately the Mushroom Virus X (MVX) disease, believed to be induced by virus infection, has raised major concern (SonNENBERG et al., 1995). According to several authors, the MVX disease is associated with a broad range of symptoms, including sporophore malformations, brown colouring, dramatic yield losses, delayed flushes, etc. (GAZE et al., 2000; GrogAn et al., 2003; ADIE et al., 2004). Such symptoms, however, can also result from errors in cropping technology

\footnotetext{
* To whom correspondence should be addressed.

Phone: +36-1-482-6313; fax: +36-1-209-6388; e-mail: noemi.lukacs@uni-corvinus.hu
} 
or through bad hygienic conditions; therefore, the appearance of disease symptoms does not necessarily indicate the presence of a pathogenic mycovirus (RAO et al., 2007).

The situation is even more complex: Whereas in LIV-diseased samples all 9 viral dsRNA segments can always be consistently detected, altogether 26 different dsRNAs $(0.6 \mathrm{kbp} ; 0.8$ kbp; $1.1 \mathrm{kbp} ; 1.6 \mathrm{kbp} ; 1.8 \mathrm{kbp} ; 2.0 \mathrm{kbp} ; 2.2 \mathrm{kbp} ; 2.4 \mathrm{kbp} ; 3.3 \mathrm{kbp} ; 3.6 \mathrm{kbp} ; 4.1 \mathrm{kbp} ; 4.8 \mathrm{kbp}$; $5.4 \mathrm{kbp} ; 5.9 \mathrm{kbp} ; 6.6 \mathrm{kbp} ; 7.0 \mathrm{kbp} ; 7.8 \mathrm{kbp} ; 8.6 \mathrm{kbp} ; 9.4 \mathrm{kbp} ; 10.25 \mathrm{kbp} ; 12.6 \mathrm{kbp} ; 13.6 \mathrm{kbp}$; $14.4 \mathrm{kbp} ; 16.2 \mathrm{kbp} ; 18.3 \mathrm{kbp} ; 20.2 \mathrm{kbp}$ ) have been found in various different MVX-diseased mushroom samples, but have never been detected together in a single sample (GrogAn et al., 2003; AdIE et al., 2004). At least 3 of these dsRNAs (2.4 kbp; 9.4 kbp; $16.2 \mathrm{kbp}$ ) are routinely detectable in healthy fruit bodies, leaving 23 disease-associated dsRNAs as possible candidates for the causative agent(s) (Grogan et al., 2003; ADIE et al., 2004). Interestingly, the symptoms also seem to differ by geographical location: The 'patch' problem, i.e. occurrence of discrete areas without mushrooms growing is more prevalent in the UK, while browning symptoms are seen mainly in Ireland, Belgium, The Netherlands, and lately also in Poland (PudeŁKo, 2010). This indicates that the term "MVX" is probably a catch-all term to describe more than one disease with uncharacterized causal agents of unknown origin.

Several results point towards the complex origin of MVX dsRNAs. RAO and co-workers (2008) have identified a browning factor, the lipodepsipeptide tolaasin, produced by Pseudomonas tolaasii and P. syringae strains which co-colonise the skin of mushrooms. Earlier results reviewed by RAO and co-workers (2007) suggest that the 4 low molecular weight dsRNA bands (sizes $2.0,1.8,0.8$ and $0.6 \mathrm{kbp}$ ) occurring concomitantly with mushroom browning symptoms may also be induced by certain environmental stress responses (Sonnenberg \& LAVRiJsSen 2004). Recently, Burton and co-workers (2011) put forward the hypothesis that the browning symptom is caused by a Partitivirus with genomic dsRNAs of 2.0 and $1.8 \mathrm{kbp}$. The pinning disruption and other symptoms were described as being associated with larger molecular weight dsRNAs between 3.6 and $14.4 \mathrm{kbp}$ (GROGAN et al., 2003; SonNenBerg \& LAVRIJSSEN 2004). A novel virus, namely Agaricus bisporus endornavirus (AbEV1; $14.4 \mathrm{kbp}$ dsRNA) was separated from the MVX complex and characterized by MAFFETTONE (2007).

Since the causative agent is not known and a complex pattern of dsRNAs is associated with the disease, MVX detection is presently mainly based upon the purification of dsRNA by CF11 column chromatography and identification of dsRNA bands after agarose gel electrophoresis (GAZE et al., 2000; GROGAN et al., 2004). We introduced dsRNAimmunoblotting as a sensitive, simple and reliable immunological method to detect potentially all dsRNA-species present in mushrooms. In this procedure dsRNA-specific monoclonal antibodies are used (SCHÖNBORN et al., 1991). They specifically recognize dsRNA independent of its nucleotide composition and sequence and do not cross-react with short double strand helices present in single-stranded RNAs. The method has been successfully used to detect infection caused by many different viruses in plants and has a sensitivity of 40-60 pg dsRNA/50 $\mu \mathrm{g}$ total nucleic acid/lane (LukÁCs, 1994). We used this method to detect dsRNA species in healthy and diseased cultivated champignons, in wild Agaricus species growing in Hungary, and in fungi co-existing with champignons during production. Our aim was to find out how frequently putative viral dsRNAs occur in these systems and to what extent they can contribute to the complex dsRNA pattern associated with the MVX disease complex. 


\section{Materials and methods}

\subsection{Fungal material}

Cultivated mushrooms with and without symptoms were collected from commercial sites, LIV and MVX reference samples were obtained from the reference collection of A. Sonnenberg, Wageningen, The Netherlands. Some strains of white button mushroom as well as the Trichoderma, Dactylium and Mycogone isolates originated from the collection of Quality Champignons Ltd., Demjén, Hungary. The wild Agaricus species without any visible symptoms were collected from different regions in Hungary. The samples were lyophilized and stored at $-20^{\circ} \mathrm{C}$ until testing. The initial amounts were usually $2 \mathrm{~g}$ fresh mycelia.

\subsection{Total nucleic acid extraction}

Lyophilized and powdered fruiting bodies and mycelia were used for sample preparation, because otherwise the high water content and the presence of secondary metabolites in the mushroom lowered the yield and the purity of the extract. Extraction was carried out by applying different CTAB (hexadecyl trimethyl-ammonium bromide) concentrations as described by GEÖSEL (2007), based on the procedures of GóES-NETO and co-workers (2005) and PEARSON and co-workers (2006). Chloroform-isoamyl-alcohol (24:1) was used to remove proteins.

\subsection{Detection of $d s R N A$ by immunoblotting}

Unfractionated nucleic acid extracts were separated by gel electrophoresis in non-denaturing $5 \%$ polyacrylamide- $1 \times \mathrm{TBE}(89 \mathrm{mM}$ Tris- $\mathrm{HCl}, 89 \mathrm{mM}$ boric acid and $2.5 \mathrm{mM}$ EDTA) gels. Using polyacrylamide gels is essential, because after agarose gel electrophoresis the sensitivity of immunodetection is reduced by about hundredfold. We routinely loaded 30-50 $\mathrm{mg}$ nucleic acid/lane. After gel electrophoresis and blotting to positively charged Biodyne B (BioRad) membranes, dsRNAs were detected on immunoblots as described by LukÁCS (1994). Commercially available DNA markers or purified rice dwarf virus (RDV) dsRNAs were used as markers.

\subsection{Detection of dsRNA by CF11 chromatography and agarose gel electrophoresis}

DsRNA isolation by CF11 cellulose column chromatography was carried out as described by DoDDS and co-workers (1984). Eluted dsRNAs were separated on $0.7 \%$ agarose gels in $1 \times$ TBE ( $89 \mathrm{mM}$ Tris-HCl, $89 \mathrm{mM}$ boric acid and $2.5 \mathrm{mM}$ EDTA) and stained with ethidiumbromide.

\section{Results and discussion}

\subsection{Detection of dsRNA in symptom-free samples of cultivated champignon strains}

CF11 cellulose chromatography and dsRNA-immunoblotting were used to investigate the occurrence of dsRNA in healthy samples of cultivated A. bisporus strains. As shown in Fig. 1a and b, after CF11 purification we found the same dsRNA pattern in several samples from a local market as described in the literature (GAZE et al., 2000; ADIE et al., 2004). In accordance 
with the literature 3 dsRNA species were present in samples A-C, with estimated molecular masses of 16.2, $9.4 \mathrm{kbp}$ and $2.4 \mathrm{kbp}$ (Fig. 1b). The dsRNAs were also detected by immunoblotting in all three samples, but because the two larger species do not separate in 5\% polyacrylamide gels, only two bands, a broad one representing the two co-migrating dsRNAs and the $2.4 \mathrm{kbp}$ band can be seen in Fig. 1a. In sample A an additional, smaller species also became visible on immunoblots. The result clearly shows that dsRNA-immunoblotting is sensitive enough to detect dsRNA in unfractionated extracts of champignon. Each of the two methods, however, has its own advantages and limitations. Whereas a relatively large sample is needed for the chromatographic procedure, for immunoblotting $2 \mathrm{~g}$ fresh weight is sufficient even for carrying out repeated analyses. On the other hand, immunoblotting has to be proceeded by polyacrylamide gel electrophoresis (LuKÁCs, 1994), which does not allow exact determination of molecular weights for dsRNA longer than $4 \mathrm{kbp}$, but is reliable and highly sensitive below this range.

a

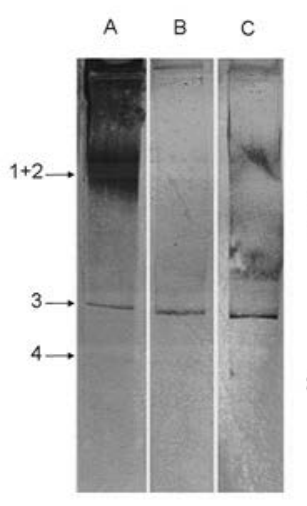

b

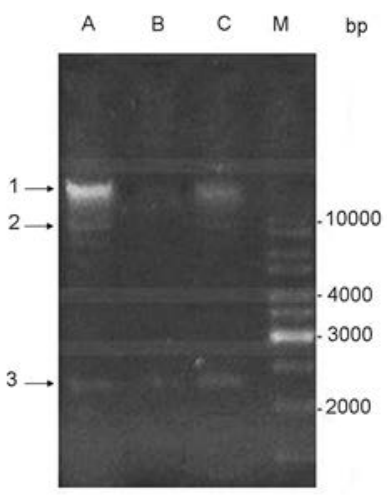

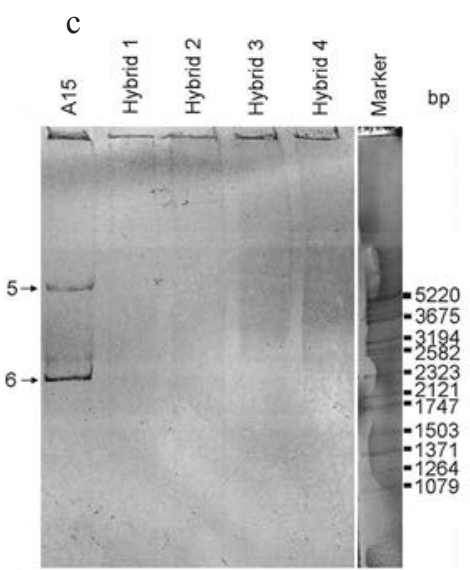

Fig. 1. dsRNA pattern of symptomless fruiting bodies of cultivated A. bisporus.

( $a$ and $b$ ) Comparison of dsRNA pattern of three independent samples (A-C) using immunoblotting (a) or CF11 chromatography followed by separation on agarose gels (b). High molecular weight dsRNAs (bands 1 and 2) were not dissolved on 5\% PAA gel, but in sample A an additional dsRNA (band 4, $1.9 \mathrm{kbp}$ ) band became visible after immunological detection (a). The length of dsRNAs was estimated by using the 1 kbp DNA ladder from Fermentas. (c) Immunoblot analysis of dsRNA segments of the widely cultivated healthy A15 A. bisporus strain and of four hybrid strains. While the A15 strain contains two dsRNA bands, the others completely lack them.

PeqGold Genome Sizer I was used as marker

It is a special characteristic of the Hungarian mushroom industry that in addition to the most frequently used A15 (Sylvan Inc.) strain several other strains are also in use. When further samples were collected from commercial growers and local markets, in several new hybrids produced in Hungary no dsRNA was detected (compare the staining pattern of the extract from A15 to that of the extracts in lanes Hybrid 1-4 in Fig. 1c. Although neither the origin nor the role of the dsRNAs in non-diseased champignons are known, the combinations of them that are found and their consistent presence/absence seem to be characteristic for individual strains. 


\subsection{Detection of dsRNA in diseased champignon fruiting bodies by immunoblotting}

Detectability of foreign, presumably viral, dsRNAs was investigated in La France Disease Virus- (LIV) and MVX-infected samples and in three samples showing MVX-like symptoms. The LIV-infected sample was used as positive control and to exclude LIV infection in the unknown samples. All 9 LIV dsRNAs gave strong signals on the blot (Fig. 2a), but no LIVlike pattern was seen in any of the apparently diseased "MVX-like" samples (Fig. 2b). In both MVX reference samples as well as in the samples showing symptoms 'Inf. 1' and 'Inf. 2' a prominent $4.1 \mathrm{kbp}$ dsRNA band can be seen in addition to the dsRNAs that are also present in healthy control samples represented by 'Eg' in Fig. 2b. A 4.1 kbp dsRNA is known to be present in MVX diseased samples, although at low frequency (ADIE et al., 2004). In sample 'Inf. 2' other dsRNA species between 1.3-2.6 kbp were also present. Despite the strong symptoms shown by the fruiting body, only very weak dsRNA bands, not detected in the MVX reference sample, were observed in sample 'Inf. 3'.

a

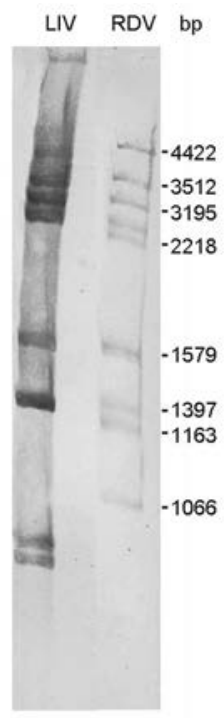

$\mathrm{b}$

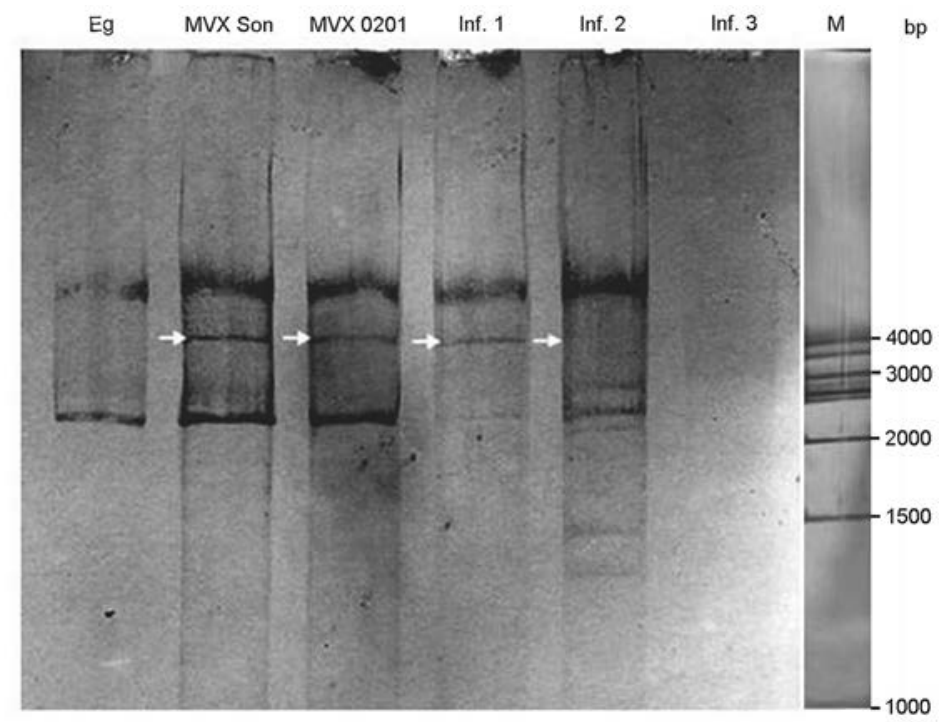

Fig. 2. Immunoblot analysis of virus-infected and symptom-bearing samples. (a) All 9 dsRNA species of LIV virus can be detected by immunoblotting in the extract of LIV-infected champignon (lane LIV). RDV genomic dsRNAs were used as markers. (b) DsRNA-species in healthy (Eg), MVX-infected reference (MVX Son, MVX 0201), and in three further samples showing MVX-like symptoms (Inf. 1-3). In addition to the two dsRNA bands also present in the healthy control (Eg), a prominent $4.1 \mathrm{kbp}$ dsRNA band (white arrow) was detected in the MVX reference samples as well as in the symptom-bearing samples 'Inf. 1' and 'Inf. 2'. In 'Inf. 2' other dsRNA species between 1.3-2.6 kbp can also be seen. In sample 'Inf. 3' only very weak dsRNA bands, not detected in the MVX reference sample, were observed. The molecular weight was estimated by using the $1 \mathrm{~kb}$ DNA ladder from Fermentas (M)

The presence of the $4.1 \mathrm{kbp}$ dsRNA in samples A and B might indicate that the MVX disease has reached Hungary, but since this dsRNA species has not been shown to be (one of) the causative agent(s) of the disease, and since we do not have sequence information about 
the identity of these co-migrating species, the conclusion does not necessarily follow from our results. The analysis, however, clearly demonstrates how complex the situation is and how badly a reliable collection of well-characterized reference samples is needed.

\subsection{Occurrence of $d s R N A$ in fungi coexisting with A. bisporus in mushroom cultivation}

Since our results described above as well as recent studies reported in the literature suggest multiple origins of the 23 dsRNA segments previously correlated with MVX (GEÖSEL et al., 2008), it seemed advisable to investigate whether some of the dsRNAs could arise from parasitic and co-habiting fungal species and not from A. bisporus itself. ANTAL and co-workers (2005) detected dsRNA elements in different Trichoderma strains isolated in Hungary. They found that the proportion of strains carrying dsRNAs was higher in isolates from mushroom farms than in soil-born ones. Therefore we investigated the dsRNA-content of 11 Trichoderma and 3 other fungal isolates from the collection of Quality Champignons Ltd., Hungary. All isolates originated from mushroom farms. The results shown in Table 1 and in Fig. 3 demonstrate the presence of dsRNAs in 4 of the 11 examined Trichoderma strains, albeit usually at a very low concentration. Isolate Trichoderma 2 is an exception, in which an extremely high concentration of dsRNA was found (Fig. 3). The Dactylium sample also contained three separable dsRNA bands, between 1.3 and $2.4 \mathrm{kbp}$. In the case of Mycogone, not a sterilely grown fungal isolate, but a distorted Mycogone-diseased Agaricus fruitbody was analysed, therefore we cannot exclude the possibility that some of the seven relatively short dsRNA species originated from the Agaricus sporophore itself.

Table 1. DsRNAs detected in microorganisms coexisting with A. bisporus in mushroom farming

\begin{tabular}{lcl}
\hline Strain & $\begin{array}{c}\text { Number of } \\
\text { dsRNAs }\end{array}$ & \multicolumn{1}{c}{ dsRNA size } \\
\hline Trichoderma 1 & - & \\
Trichoderma 2 & 6 & $1.4 \mathrm{kbp} ; 1.5 \mathrm{kbp} ; 3.1 \mathrm{kbp} ; 3.5 \mathrm{kbp} ; 3.7 \mathrm{kbp} ; 4.4 \mathrm{kbp}$ \\
Trichoderma 3 & - & - \\
Trichoderma 4 & 1 & $1.9 \mathrm{kbp}$ \\
Trichoderma 5 & - & - \\
Trichoderma 6 & - & - \\
Trichoderma 7 & - & - \\
Trichoderma 8 & 5 & $1.1 \mathrm{kbp} ; 1.7 \mathrm{kbp} ; 1.8 \mathrm{kbp} ; 2.4 \mathrm{kbp} ; 2.5 \mathrm{kbp}$ \\
Trichoderma 9 & - & - \\
Trichoderma 10 & - & - \\
Trichoderma 11 & 5 & $3.1 \mathrm{kbp} ; 3.2 \mathrm{kbp} ; 3.9 \mathrm{kbp} ; 4.6 \mathrm{kbp} ;>5 \mathrm{kbp}$ \\
Dactylium & 3 & $1.3 \mathrm{kbp} ; 2.3 \mathrm{kbp} ; 2.4 \mathrm{kbp}$ \\
Verticillium & - & - \\
Mycogone-diseased sporophore & 7 & $1.5 \mathrm{kbp} ; 2.1 \mathrm{kbp} ; 2.4 \mathrm{kbp} ; 2.5 \mathrm{kbp} ; 3.0 \mathrm{kbp} ; 3.8 \mathrm{kbp} ; 4.4 \mathrm{kbp}$ \\
\hline
\end{tabular}




\subsection{DsRNA in wild Agaricus sporophores}

Two reasons prompted us to analyse whether dsRNAs potentially indicating the presence of a virus also occur in wild Agaricus species in nature and whether the dsRNA patterns show any relatedness to that of LIV- or MVX-infected cultivated mushroom samples: (i) Feral Agaricus species are potential breeding sources of new champignon varieties. (ii) Growing in their natural habitat, their coexistence with microscopic fungi and other microorganisms is not influenced by artificial culture conditions or compost material. Twenty-five species from different habitats in Hungary were collected, and in total 56 biologically independent samples were investigated (Table 2). To be able to identify safely the very large and middle sized dsRNAs, CF11 chromatography as well as immunoblot analysis were also carried out.

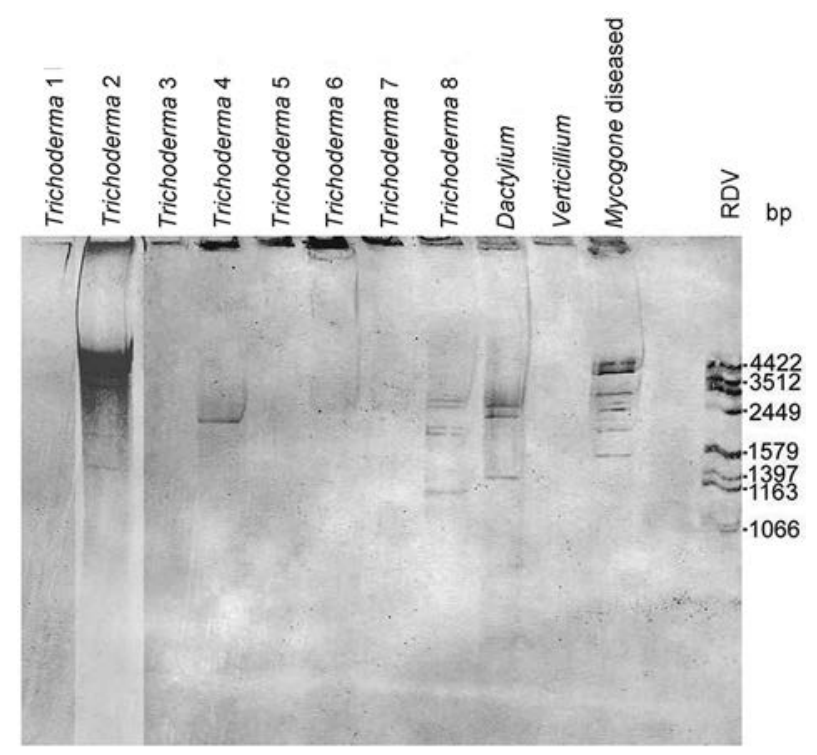

Fig. 3. dsRNA pattern in fungal isolates from champignon farms. dsRNA bands of variable length can be seen in Trichoderma strains 2, 4 and 8, in the Dactylium isolate and in the Mycogone-infected sporophore. Rice dwarf virus (RDV) genomic dsRNA extract was used as marker

Table 2. Occurrence of dsRNAs in different wild Agaricus fruitbodies

\begin{tabular}{lccc}
\hline Species & Habitat type & Number of dsRNAs & dsRNA size \\
\hline A. bisporus (1) & grassland & 1 & $>5 \mathrm{kbp}$ \\
A. bisporus (2) & grassland & - & \\
A. bisporus (3) & grassland & - & \\
A. bitorquis (1) & grassland & 1 & $>5 \mathrm{kbp}$ \\
A. bitorquis (2) & grassland & - & \\
A. bitorquis (3) & grassland & - & \\
\hline
\end{tabular}


Table 2. Continued

\begin{tabular}{|c|c|c|c|}
\hline Species & Habitat type & Number of dsRNAs & dsRNA size \\
\hline A. campestris (1) & grassland & 4 & $3.5 \mathrm{kbp} ; 3.7 \mathrm{kbp} ; 3.8 \mathrm{kbp} ;>5 \mathrm{kbp}$ \\
\hline A. campestris (2) & grassland & 4 & $1.8 \mathrm{kbp}, 1.9 \mathrm{kbp} ; 2.3 \mathrm{kbp} ; 2.4 \mathrm{kbp}$ \\
\hline A. campestris (3) & grassland & - & \\
\hline A. deylii & forest & - & \\
\hline A. floccipes & grassland & - & \\
\hline A. gennadii (1) & grassland & 4 & $1.1 \mathrm{kbp} ; 1.8 \mathrm{kbp} ; 1.9 \mathrm{kbp} ;>5 \mathrm{kbp}$ \\
\hline A. gennadii (2) & grassland & - & \\
\hline A. haemorrhoidarius & forest & - & \\
\hline A. iodosmus & grassland & - & \\
\hline A. lanipes & forest & - & \\
\hline A. lutosus & grassland & - & \\
\hline A. macrocarpus & forest & - & \\
\hline A. maskae (1) & grassland & 2 & $1.8 \mathrm{kbp} ; 3.7 \mathrm{kbp}$ \\
\hline A. maskae (2) & grassland & 3 & $1.6 \mathrm{kbp} ; 1.8 \mathrm{kbp} ;>5 \mathrm{kbp}$ \\
\hline A. meleagris (1) & forest & 7 & $\begin{array}{l}1.6 \mathrm{kbp} ; 1.7 \mathrm{kbp} ; 1.8 \mathrm{kbp} ; 1.9 \mathrm{kbp} ; 2.0 \mathrm{kbp} ; 2.2 \mathrm{kbp} \text {; } \\
2.4 \mathrm{kbp}\end{array}$ \\
\hline A. meleagris (2) & forest & - & \\
\hline A. meleagris (3) & forest & - & \\
\hline A. pampeanus & grassland & - & \\
\hline A. phaeolepidotus (1) & forest & - & \\
\hline A. phaeolepidotus (2) & forest & - & \\
\hline A. phaeolepidotus (3) & forest & - & \\
\hline A. phaeolepidotus (4) & forest & - & \\
\hline A. pilatianus (1) & grassland & 4 & $1.65 \mathrm{kbp} ; 1.7 \mathrm{kbp} ; 2.1 \mathrm{kbp} ; 2.2 \mathrm{kbp}$ \\
\hline A. pilatianus (2) & grassland & - & \\
\hline A. pilatianus (3) & grassland & - & \\
\hline A. pilatianus (4) & grassland & - & \\
\hline A. pil. var. magnus & grassland & - & \\
\hline A. porphyrizon (1) & forest & - & \\
\hline A. porphyrizon (2) & forest & - & \\
\hline A. romagnesii (1) & grassland & 5 & $1.6 \mathrm{kbp} ; 1.7 \mathrm{kbp} ; 1.8 \mathrm{kbp} ; 1.9 \mathrm{kbp} ;>5 \mathrm{kbp}$ \\
\hline A. romagnesii (2) & grassland & 2 & $1.7 \mathrm{kbp} ; 1.8 \mathrm{kbp}$ \\
\hline A. romagnesii (3) & grassland & - & \\
\hline A. semotus (1) & forest & - & \\
\hline A. semotus (2) & forest & - & \\
\hline A. squamuliferus (1) & forest & 5 & $1.2 \mathrm{kbp} ; 1.3 \mathrm{kbp} ; 1.7 \mathrm{kbp} ; 1.8 \mathrm{kbp} ; 1.9 \mathrm{kbp}$ \\
\hline A. squamuliferus (2) & forest & - & \\
\hline
\end{tabular}


Table 2. Continued

\begin{tabular}{llcl}
\hline Species & Habitat type & $\begin{array}{c}\text { Number of } \\
\text { dsRNAs }\end{array}$ & dsRNA size \\
\hline A. squamuliferus (3) & forest & - & \\
A. sylvaticus & forest & - & $1.8 \mathrm{kbp} ; 2.0 \mathrm{kbp} ; 3.1 \mathrm{kbp} ; 3.3 \mathrm{kbp} ; 3.4 \mathrm{kbp} ; 3.9 \mathrm{kbp}$ \\
A. sylvicola & forest & 6 & $1.3 \mathrm{kbp} ; 1.4 \mathrm{kbp} ; 1.5 \mathrm{kbp} ; 1.7 \mathrm{kbp} ; 1.9 \mathrm{kbp} ; 2.0 \mathrm{kbp} ;$ \\
A. vaporarius (1) & grassland & 7 & $>5 \mathrm{kbp}$ \\
A. vaporarius (2) & grassland & 4 & $1.7 \mathrm{kbp} ; 1.8 \mathrm{kbp} ; 1.9 \mathrm{kbp} ; 2.0 \mathrm{kbp}$ \\
A. xanthoderma (1) & grassland & 3 & $1.9 \mathrm{kbp} ; 2.0 \mathrm{kbp} ; 2.1 \mathrm{kbp}$ \\
A. xanthoderma (2) & grassland & - & \\
A. xanthoderma (3) & grassland & - & \\
A. xanthoderma (4) & grassland & - & \\
A. “Rubescentes” & grassland & - & \\
\hline
\end{tabular}

We detected dsRNAs of potentially viral origin in 16 of the 56 samples, representing 12 Agaricus species (Table 2 and Fig. 4). A. bitorquis, A. vaporarius, A. bisporus, A. campestris, A. maskae, A. romagnesii, A. xanthoderma, A. pilatianus, A. meleagris, A. sylvicola, A. squamuliferus and $A$. gennadii were found to be dsRNA positive, and in one case, for $A$. vaporarius, differences in the dsRNA pattern of two independent samples were observed (compare the corresponding lanes in Fig. 4b).

a

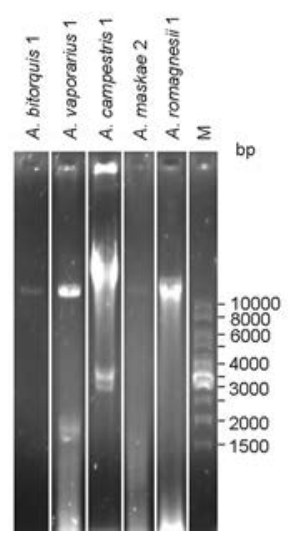

b

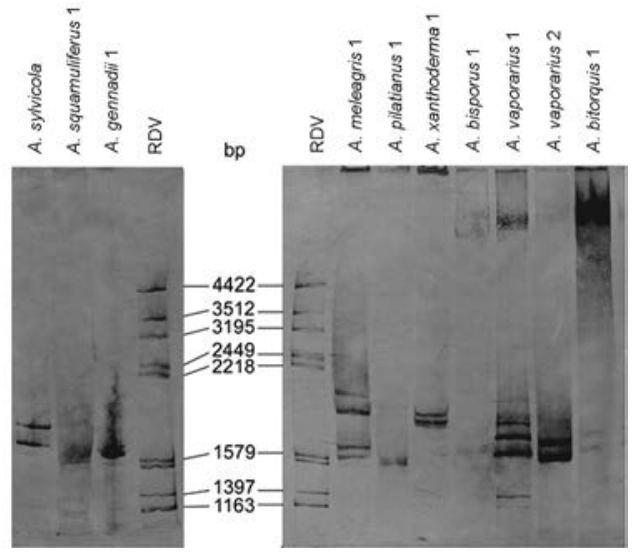

Fig. 4. dsRNA pattern in wild Agaricus species. (a) Endornavirus-like dsRNA (>10 kbp) was detected in all 5 wild Agaricus species collected from natural habitats. Crude nucleic extracts were purified by CF11 chromatography and eluted dsRNAs were separated on 1\% agarose gels. In addition to the large dsRNA in two samples smaller dsRNAs can also be seen. The $1 \mathrm{kbp}$ DNA ladder from Fermentas was used as marker (M). (b) Smaller dsRNA species in the size range of partitiviruses were detected in several samples by immunoblot analysis. In A. bitorquis 1 and $A$. vaporarius 1 samples more dsRNAs were detected in the lower size range by immunoblotting than by

CF11 chromatography. Rice dwarf virus (RDV) genomic dsRNAs were used as markers 
LIV was not present in the wild Agaricus species tested, because its characteristic and easily detectable dsRNA pattern was not seen. Because of the complex dsRNA pattern occurring in association with the MVX disease, at present we can neither confirm nor exclude any identity between MVX-associated dsRNA and those of the wild Agaricus species. As shown in Fig. 4a, in five samples, i.e. in A. bitorquis, A. vaporarius, A. campestris, A. maskae and $A$. romagnesi, a very large dsRNA $(\geq 12 \mathrm{kbp})$ was detected with variable signal intensity. This size is characteristic for endornaviruses, and an endornavirus, AbEV1 has already been characterized in A. bisporus (MAFFETtone, 2007). A similarly large, but rather faint band can also be seen in the wild A. bisporus sample 1 (Fig. 4b). We believe that the large dsRNAs detected in the above-mentioned species, represent the genomic dsRNA of an endornavirus. We plan to carry out RT-PCR studies to find out whether these viruses are related to or may even be identical to AbEV1. In the remaining positive samples we detected smaller dsRNAs with varying concentrations in the different samples. In some cases, e.g. in the A. meleagris, A. xanthoderma and A. vaporarius samples in Fig. 4b, the pair-wise occurrence and size of the dsRNA bands correspond well to that of the partitiviruses. If we presume that these bands indeed represent genomic dsRNA of the genus Partitivirus of Partitiviridae family, then on the basis of the electrophoretic mobility of the molecules at least 4 different viruses may be present in our samples. The presence of the partitiviruses needs further investigation, especially to follow up Burton's proposal that the presence of browning symptoms can be causally connected with the presence of a partitivirus (BURTON et al., 2011). Browning symptoms were not seen in any of the feral Agaricus samples.

All things considered, our results show that different dsRNA species, i.e. potential viruses, do occur in wild Agaricus species. It is therefore highly advisable to carry out a careful analysis of dsRNA-patterns before new wild samples are introduced as hybridization partners or new candidates for cultivation.

\section{Conclusions}

Detection of MVX-disease is presently based on comparison of dsRNA-pattern of healthy and diseased samples. In this paper we have shown that dsRNA-immunoblotting can be used for dsRNA detection in Agaricus species. The advantages of the method are its sensitivity and the small sample size needed. We propose to use this method as first screening for putative virus infection, especially when no viral sequence information is available. Although the size of dsRNAs up to $4 \mathrm{kbp}$ can be reliably determined by immunoblotting, the method is not a substitute for the sequence-specific virus identification by PCR, especially in those cases where such a complex dsRNA-pattern can be present as in "MVX disease".

We used immunoblotting and CF11 chromatography to investigate which dsRNAs are present in healthy and symptom-bearing cultivated champignons, in microscopic fungi associated with them, and in feral Agaricus species. In MVX reference samples and two symptom-bearing fruitbodies a $4.1 \mathrm{kbp}$ dsRNA, not present in the extract of healthy sporophores, was detected but no other dsRNA species were found by immunoblotting. Highly variable dsRNA patterns were detected in a significant proportion of wild Agaricus sporophores and in microscopic fungal species coexisting with champignons during cultivation. These dsRNA bands mostly differed in size from those associated with the MVX complex. Our results show a wide range of dsRNAs - potentially viral genetic material - in organisms found in the mushroom farming and breeding ecosystem. This should be taken 
into consideration in mushroom cultivation development. With respect to the so-called MVX disease, our results support the hypothesis that the 23 dsRNA species associated with the socalled MVX disease (RAO et al., 2008) are of polyphyletic origin and may even originate from other organisms living around the hyphae of Agaricus.

The present work was supported by grants GVOP-3.3.3-05/1.-2005-05-0106/3.0 and TÁMOP 4.2.1/B-09/1/KMR2010-0005.

\section{References}

Adie, B., Choi, I., Soares, A., Holcroft, S., Eastwood, D., Mead, A., Grogan, H., Kerrigan, R., Challen, M. \& Mills, P. (2004): MVX disease and double-stranded RNA elements in Agaricus bisporus. Mushroom Sci., 16, $411-420$.

Antal, Z., Hatvani, L., Varga, J., Kredics, L., Szekeres, A., Manczinger, L., Vágvölgyi, C. \& Nagy, E. (2005): Double-stranded RNA elements in Trichoderma strains obtained from mushroom farms. Acta Microbiol. Immun. Hung., 52, Suppl. 5-6.

Burton, K., Green, J., Baker, A., Eastwood, D. \& Grogan, H. (2011): Mushroom Virus X - The identification of brown cap mushroom virus and a new highly sensitive diagnostic test for phase III compost. Proceedings of the 7th International Conference on Mushroom Biology and Mushroom Products (ICMBMP7), Arcachon, France, pp. 466-473.

Dodds, J.A., Morris, T.J. \& Jordan, R.L. (1984): Plant viral double-stranded RNA. Ann. Rev. Phytopathology, 22, $151-168$.

Elibuyuk, I. \& Bostan, H. (2010): Detection of a virus disease on white button mushroom (Agaricus bisporus) in Ankara, Turkey. Int. J. Agric. Biol., 12, 597-600.

Gaze, R.H., Calvo-Bado, L., Challen, M.P., Adie, B. \& Romaine, C.P. (2000): A new virus disease of Agaricus bisporus? -in: Van Griensven, L.J.L.D. (Ed.), Science and cultivation of edible fungi Balkema. Rotterdam, Netherlands, 2, pp. 701-705.

Geösel, A. (2007): Immundiagnosztikai eljárás kidolgozása a csiperkében elöforduló virusok kimutatására. (Szakdolgozat.) (Development of immunodiagnostic procedure for detection of viruses occurring in champignon. Thesis) BCE-KETK, Növényélettan és Növényi Biokémia Tanszék. (Department of Plant Physiology and Plant Biochemistry.) 51 pages.

Geösel, A., Halász, K., Szarvas, J. Hajdú, Cs. Virágh, N. \& Lukács, N. (2008): Immunological detection of dsRNAs in wild Agaricus species and in virusinfected cultivated champignon. Proceedings of the Sixth International Conference on Mushroom Biology and Mushroom Products. 30.09.-04.10. 2008, Bonn, Germany, pp. 148-154.

Góes-Neto, A., Loguercio-Leite, C. \& Guerrero, R.T. (2005): DNA extraction from frozen field-collected and dehydrated herbarium fungal basidiomata: performance of SDS and CTAB-based methods. Biotemas, 18, 19-32.

Grogan, H.M., Adie, B.A., Gaze, R.H., Challen, M.P. \& Mills, P.R. (2003): Double-stranded RNA elements associated with the MVX disease of Agaricus bisporus. Mycological Res., 107, 147-154.

Grogan, H.M., Tomprefa, N., Mulcachy, J., Holcroft, S. \& GaZe, R.H. (2004): Transmission of Mushroom Virus $\mathrm{X}$ disease in crops. Mushroom Sci., 16, 489-498.

LuKÁCs, N. (1994): Detection of virus infection in plants and differentiation between coexisting viruses by monoclonal antibodies to double-stranded RNA. J. Virological Meth., 47, 255-272.

Maffettone, E. (2007): Characterization of a novel virus associated with the MVX disease of Agaricus bisporus. Ph.D. Thesis. Cranfield University, Cranfield, 249 pages.

Pearson, G.A., Lago-Leston, A., Valente, M. \& Serrão, E.A. (2006): Simple and rapid RNA extraction from lyophilized tissue of brown algae and seagrasses. Eur. J. Phycology, 41, 97-104.

PudeŁko, K. (2010): Mushroom Virus X (MVX): A novel disease of mushrooms in Poland? J. Pl. Prot. Res., 50, $366-371$.

Rao, J.R., Nelson, D.W.A. \& McClean, S. (2007): The enigma of double-stranded RNA (dsRNA) associated with Mushroom Virus X (MVX). Curr. Issues Molecular Biol., 9, 103-121. 
RaO, J.R., Nelson, D.W.A. \& McCleAn, S. (2008): Expressions for cell growth regulating genes (cAMP, protein kinase) after perceiving viral dsRNAs or factors associated with browning mushrooms infected with virus $\mathrm{X}$ patch disease. ISMS, 17(1), Article 78.

Schönborn, J., Oberstass, J., Breyel, E., Tittgen, J., Schumacher, J. \& LukÁcs, N. (1991): Monoclonal antibodies to double-stranded RNA as probes of RNA structure in crude nucleic acid extracts. Nucleic Acids Res., 19 , 2993-3000.

SonNenBerg, A.S.M. \& LavriJssen, B. (2004): Browning of mushrooms and the presence of viral double-stranded RNA in Dutch mushrooms. -in: Romaine, C.P., Keil, C.B., Rinker, D.L.R. Royse, D.J. (Eds), Science and cultivation of edible and medicinal fungi. The Pennsylvania State Univ., University Park, PA., USA, pp. 541-546.

Sonnenberg, A.S.M., Van Kemper, I.P.J. \& VAn Griensven, L.J.L.D. (1995): Detection of Agaricus bisporus viral dsRNAs in pure cultures, spawn, and spawn-run compost by RT-PCR. Mushroom Sci., 14, 587-594. 